\title{
Evaluation of Mecidiyeköy as an urban threshold in socio-cultural sustainability framework
}

\author{
Olcay Yıldızgördü*৫ \\ Derya Yorgancioğlu**(i)
}

\begin{abstract}
The globalization process resulted from technological and economic developments in the second half of the 20th century has created a rapid urban transformation in the world and Turkey as a developing country. This rapid urban transformation has affected the urban and architectural context of cities, including Istanbul, both in negative and positive ways. Urban policies, which lay the groundwork for minimizing the negative effects of rapid urbanization on cities and producing more inclusive life scenarios, are mostly based on socio-cultural sustainability approaches. However, when urban policies are concerned, the issue of sustainability is usually approached from the perspectives of ecological and/or physical features, whereas the significance of socio-cultural sustainability for urban development strategies is often neglected. Within this framework, this study aims to examine the potentials and constraints that Mecidiyeköy encompasses as an "urban threshold" and to inquire the ways that sociocultural sustainability can offer a ground for future urban policies and architectural practices to trigger the co-existence of differences and social interaction between them. This study is designed as a case-study and the methodological framework of the study consists of literature review and on-site observations. This article revealed that socio-cultural sustainability, as a conceptual framework and urban approach, can provide a fertile ground for future urban scenarios that would be developed for Mecidiyeköy. If approached from the socio-cultural sustainability perspective, it can be ensured that this region having constraints and potentials in terms of accommodating spatial and human diversity and triggering the interaction between them, can actually work as an "urban threshold."
\end{abstract}

Keywords: socio-cultural sustainability, urban space, urban threshold, Mecidiyeköy, third space

\section{Introduction}

In the 21st century, with the technological improvements in telecommunication and transportation infrastructures, cities have become defined with multiple complex networks of interconnection. The phenomena of movement, fluidity, and speed, which manifest themselves both in physical and virtual realms, result in new models and strategies of spatial experiences and productions. While urban space becomes more accessible and rapidly experienced, the boundaries between regions, cities, districts, and neighborhoods are weakened, even blurred. On the one hand, 
this situation has the potential to increase the interaction between different urban areas, on the other hand, in some cases it brings along socio-economic and/or cultural barriers between different groups.

The encounter of people of different socio-economic and/or cultural groups sometimes creates tension and even conflict when the design of urban space and buildings are not based on inclusive design principles. Alternatively, to act as an "urban threshold" becomes the strength of some urban neighborhoods. As underlined by Teyssot (2008), "[t]he form of the threshold, as temporal and spatial figure, is that of the 'between-the-two', of the medium that opens between two things." The spatial conditions of the threshold bring forth potential for transition and connection, opening the door for possibilities of gathering and exchange of ideas between divergent phenomena (Hertzberger, 2000). Istanbul, as a metropolitan city, is reshaped through a rapid urban transformation which has a direct impact on spaces, buildings, people and their daily practices.

Mecidiyeköy is one of the most conspicuous "urban thresholds" in the city of Istanbul. While Mecidiyeköy is one of the most central points of the European side of the City in terms of urban transportation and accessibility, it also has spatial and infrastructural problems that make pedestrian movement difficult. Besides, the co-existence of low-rise residential buildings and highrise business centers result in the spatial and socio-economic segregations in the neighborhood. Its location at the intersection of transportation networks -including public transportation options such as bus, metrobus, and metro- brings it the potential of being an urban threshold; yet, the lack of public spaces prevents Mecidiyeköy from fulfilling this potential.

Alongside the above-described state of Mecidiyeköy, the absence of a common ground for encounter among diverse social identities establishes socio-cultural boundaries, both visible and invisible, between different social groups and their spatial experiences. This makes the formation and maintenance of social cohesion fragile. At this point, implementing urban development projections that takes the socio-culturally sustainable parameters into consideration is crucial for Mecidiyeköy to fulfil its potentials both as a spatial and social threshold. Within this context, this paper examines how socio-cultural sustainability approaches can provide ground for future urban policies and architectural practices and how such approaches can inquire the opportunities and restrictions that Mecidiyeköy contains as an "urban threshold."

\section{Importance of Socio-cultural Sustainability for Urban Development}

New planning and governance approaches have been proposed worldwide and in Turkey with the aim of improving the physical and natural environments, adapting cities to rapid change and reducing the side effects of urbanization, which has turned into a global phenomenon within the last thirty years. Within this context, studies focusing on "sustainability" and "sustainable development" are subjects gaining more importance in academic and professional circles (Karuppannan \& Sivam, 2011; Woodcraft, 2012). Sustainability has taken its place as the key concept that determines the governmental approaches to the urban planning system in most developed Western countries, in order to meet he economic, environmental and social needs without creating any damage for the living conditions of the future generations (Brundtland, 1987).

Although it has been emphasized that economic, environmental and social sustainability are equally important, sustainability has often been addressed from an economic and ecological perspective, while its social dimension has been relatively neglected (Dixon, 2011; Mitlin \& Satterthwaite, 1996). Nevertheless, sustainability is not only based on the physical and natural environment but also on the multidimensionality of local social and cultural environments. 
Therefore, the socio-cultural dimension of sustainability that aims to strengthen people's quality of life is crucial.

According to Oktay (2014), social sustainability can be defined as an effort to create a society with diversity and equality where the basic social needs of the inhabitants are successfully met; it encompasses "mental and physical health of all stakeholders," "community spirit," "equality of all stakeholders" and "fulfil of essential services." In other words, socio-cultural sustainability arises in forming communities with higher life quality, various, faithful, healthy, habitable, and democratic environments that enable people to participate in collective activities, recreational opportunities, and accessible public transportation (Sachs, 1999; Colantonio \& Dixon, 2011). So, social sustainability has gained increased recognition as a fundamental component for urban development projects in the 21st century (Hediger, 2000). Table 1 illustrates a list of factors discussed by theorists and practitioners as contributing to socially sustainable urban settlements.

Table 1 Urban social sustainability - contributory factors as identified in a literature review (Dempsey et al., 2011, p.291).

\begin{tabular}{|c|c|c|}
\hline \multicolumn{2}{|c|}{ Non-physical factors } & \multirow[b]{2}{*}{ 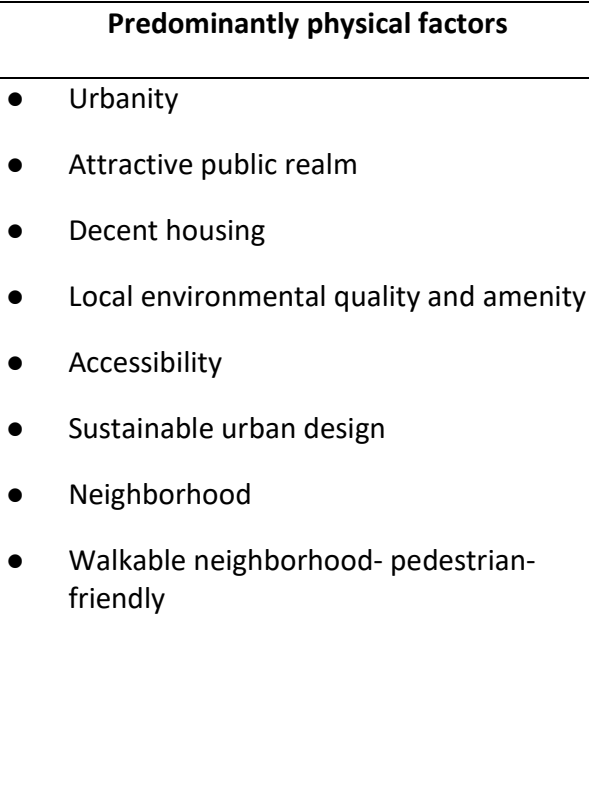 } \\
\hline $\begin{array}{l}\text { - } \text { Education and training } \\
\text { - } \text { Social justice } \\
\text { - } \text { democricipation and local } \\
\text { - } \text { wealth, quality of life and } \\
\text { - Social inclusion } \\
\text { - Social capital } \\
\text { - } \text { Community } \\
\text { - Safety } \\
\text { - Mixed tenure } \\
\text { - Fair income }\end{array}$ & 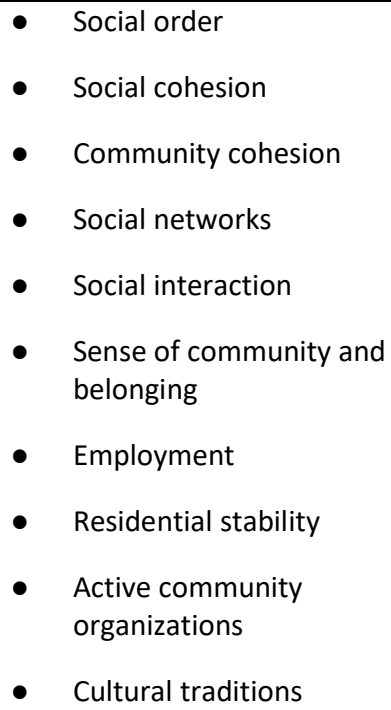 & \\
\hline
\end{tabular}

\section{Urban Condition of Istanbul}

Today, globalization that is engendered through political and economic forces creates tremendous changes both in social and everyday practices and urban spaces in which these practices take place. This transformation has both visible and invisible effects, especially in cities that are defined as living complex organisms encompassing physical, social, economic, political and cultural elements. Istanbul is no exception. As underlined by Keyder (2000), Istanbul is a cosmopolitan city with a heterogeneous population, where various cultures are mixed and accommodates "a plurality in which social groups and cultures that are often separated from each other coexist". While this pluralistic structure of Istanbul makes it one of the richest cities in the world in physical and cultural terms, it also brings about complex problems regarding the issues of urban form and identity.

Globalization, as an essential urban force, triggers a continuous condition of transformation for the multi-centered, dynamic and heterogeneous structures of metropoles, as it is the case for Istanbul (Artuç, 2016). The current urban condition of Istanbul can be defined as a result of a 
continuous process of change driven by the forces of globalization or global economy embedded through political and financial policies that have direct impact on the practices of planning and architecture (Karaman, 2008; Ozus, Turk \& Dokmeci, 2011). Today's urban complexity of Istanbul can be better understood with reference to some important breaking points in the 20th century urbanization history. While the 1950 s is shaped by the effects of increasing construction practices resulting from modernization and industrialization process, the development of urban transportation networks that connected the urban center and periphery in the 1970s opens the way for the decentralization of industry from urban centers accelerated by a transition to a liberal economy in the 1980s (Tekeli, 2013; Artuç, 2016). In the 1990s, urban space is mainly shaped by the impact liberal economy on urban policies that focused on internationalization of Istanbul; this situation increasingly continues today.

Under the impact of neo-liberal economy and global capitalist forces, Istanbul is experiencing a large-scale transformation today that creates "the new symbols of the city" (Mutman \& Yorgancıoğlu, 2021, in press). It is evident that this transformation process has many negative impacts on the physical urban space and the daily practices of the citizens. As underlined by Oktay (2014), such negative urban conditions results from "the approaches brought about by globalization, based merely on economy that serve world capitalism." However, within the scope of urban policies and architectural design practices envisaged for today's metropolises, "social sustainability" gains importance as a driving force more than ever. The development and implementation of social sustainability policies that take into consideration the direct relationship between sustainable city and high quality of urban life, with a focus on human needs, are of great importance for the city of Istanbul as well.

\section{Problem Definition, Purpose and Scope of the Study}

This study emphasizes the importance of socio-cultural sustainability approaches in reconsidering urban space problematics in order to provide a ground for future urban policies and architectural practices. In the study, Mecidiyeköy Region in Istanbul is examined within the framework of socio-cultural sustainability through a spatial reading based on Stavrides's (2010) concept of "threshold" (Stavrides, 2010; Stavrides, 2015; Şevik \& Çalışkan 2018). Within this context, the study focuses on the experiential and physical problems that create an obstacle for being an urban threshold faced in Mecidiyeköy in terms of vehicular and pedestrian accessibility and spatial and socio-economic segregations. Based on this analysis, the study aims to answer two main questions:

- Staring from the consideration that Mecidiyeköy has the potential for being an urban threshold, what are the obstacles to fulfil this potential? Is it possible to address these obstacles from the perspective of socio-cultural sustainability?

- Is it possible to offer suggestions that will contribute to future urban policies and architectural practices by inquiring about these potentials and constraints?

\section{Methodology}

The methodology applied in this study, which points to a practical and theoretical problem, consists of two phases: literature review and site observation. Initially, the literature review is based on the topic of rapid urban transformation resulting from the globalization and technological and economic developments in the second half of the 20th, with a focus on international context as well as the context of Istanbul. The impact of globalization on cities' urban and architectural context is also addressed in the literature review. Literature review revealed a direct relationship between 
socio-cultural sustainability approaches with underlying concepts and the urban threshold concept. The literature regarding the importance of socio-cultural sustainability for urban development and the urban condition of Istanbul has also been addressed. Mecidiyeköy, located on the European side of Istanbul, has been designated as a case. The selection of case study depends on several reasons; Mecidiyeköy is a neighborhood profoundly affected by urban interventions and, in parallel with these impacts, the district cannot use its full potential for being an "urban threshold".

The second phase of the case-study included a field research as an exploratory research method. According to data analysis, the research can be defined as a qualitative study that aims to examine a phenomenon's occurrence in its natural environment. Within the scope of field search: mapping, on-site observation, and snapshot methods were used. First of all, to comprehend accessibility, nodes, and flows, the mapping technique was used starting from a larger scale, focusing on the Mecidiyeköy. As a part of the research's methodological framework, a route has determined and experienced through on-site observation (Figure 1). The points that make up the stops of this route are the landmarks of the changing urban identity triggered by the urban transformation in Mecidiyeköy, as well as the elements representing the architectonic features unique to the area. The route also provides the opportunity to observe the functional, structural and experiential thresholds in the area. The route started with (1) Mecidiyeköy Metrobus Station, and continued with (2) Torun Center, (3) Fairmont Quasar Istanbul, and ended with (4) Ortaklar Avenue, which paved the way to complete a loop and arrive at the starting point (Figure 1). The snapshot method has been used to record many instant short videos to catch the instant exploration of the users' serial movements during the field research (Url-1). Finally, findings obtained from the literature review, mapping studies, on-site observations and snapshots were analyzed and synthesized in the discussion and conclusion part.

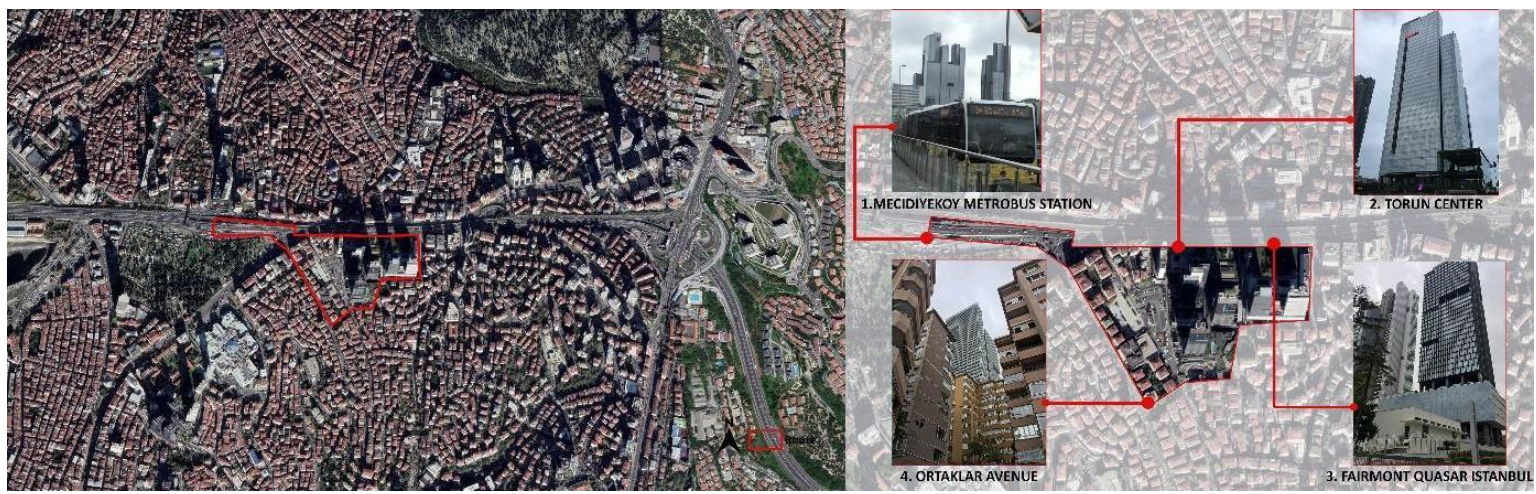

Figure 1 Aerial view of Mecidiyeköy and the route and stops of the research area (Photograph credits: personal archive of Feride Gül Keleş, 2019).

\section{Findings}

Within the scope of the study, analyses aim to investigate and elucidate architectural qualities, transportation infrastructure in Mecidiyeköy, and the sense of identity of place, spaces of integration and concept of dwelling. These findings are gathered under the two main themes: (1) transportation and accessibility issues, and (2) the identity of place.

\subsection{Transportation and Accessibility Issues}

Mecidiyeköy has a central location in Istanbul: it includes a large part of Büyükdere Avenue, one of the most bustling streets of Istanbul with headquarters of many banks and is located at the junction of transportation lines and Istanbul Ring Road. Although Mecidiyeköy used to be a region 
surrounded by graveyards and orchards and did not have many settlements during the 19th century, today, it is one of the most central and densely populated districts in Istanbul. Besides its central business district character, it is a highly structured multimodal transportation node for Istanbul based on multiple transportation opportunities (Figure 2). Gür (2019) classified the existing modes of Mecidiyeköy into four as rapid transit (metro), semi-rapid transit (metrobus), street transit (bus), and nearly all paratransit modes (dolmus, minibus, taxi-dolmus), by clarifying that Mecidiyeköy is the departure point of many of those operations. For instance, MecidiyeköyMahmutbey Metro Line (M7), which was put into service in 2020, reached 100 thousand passengers per day (IMM). This gives an idea of the density of people coming to or departing from Mecidiyeköy using only the metro line. Dişli (2006) attributed the reason Mecidiyeköy is a crucial transfer center to its vitality as a commercial and service center surrounded by dense housing settlements. Although transportation opportunities facilitate accessibility to the region, they cause some difficulties for the users and the quality of their experiences, making pedestrian accessibility problematic.
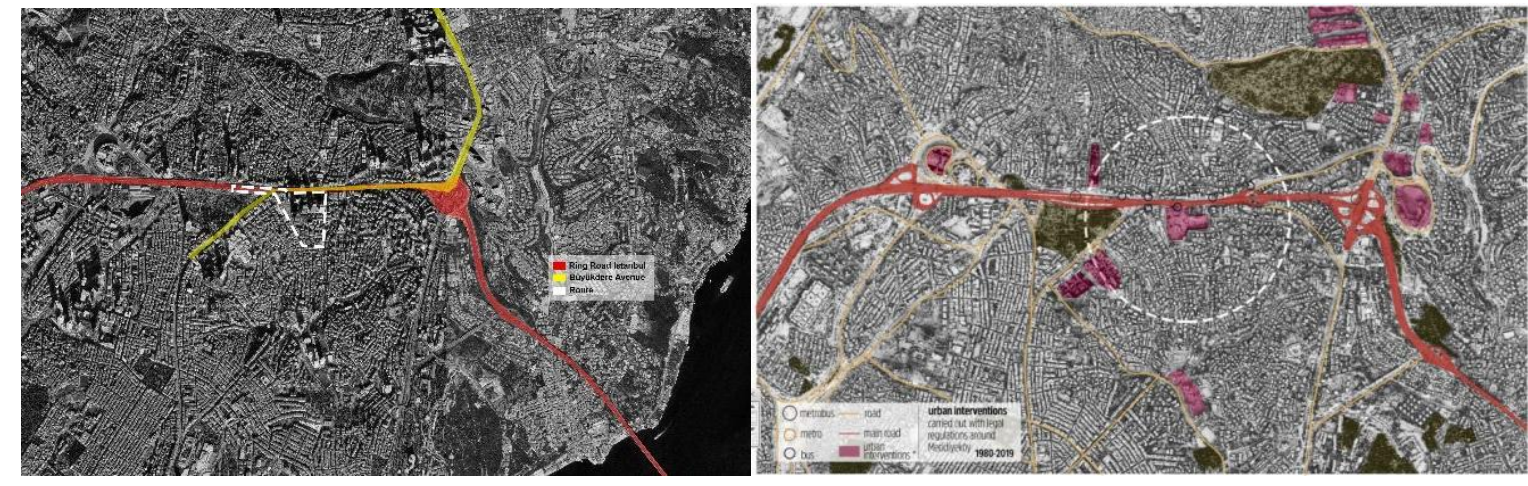

Figure 2 Mecidiyeköy's location in Istanbul (Diagram credits: the author).

Considering the features mentioned above, Mecidiyeköy is a highly active area where numerous people daily visit. People may come to Mecidiyeköy not only because they work or live there, but also because they have to stop by when they pass by while transferring to other districts. Therefore, for the pedestrians, walkability and accessibility is a vital factor in the case of Mecidiyeköy to ensure the quality of the users' experience. Within the scope of this study, it has been discovered that in Mecidiyeköy pedestrian access is enabled through the sidewalks on the streets and the underground tunnels; yet, it is quite insufficient due to the intersection of vehicular traffic and pedestrian flow (Figure 3). Gür (2019) underlines the problems related with pedestrian accessibility in Mecidiyeköy by arguing that: "The traffic is heavy, and there are many traffic lights and obstacles such as parked automobiles, selling stands, pavements' height differences, road works, and crowded streets." The physical obstacles and risky pathways not only decreases the safety of the urban environment, but also increases the travel time for the pedestrians while being transferred between nodes or walking to destinations (Figure 3). Accordingly, it can hardly be considered that Mecidiyeköy is a pedestrian-friendly region and that the pedestrian flow is comfortable and safe. 

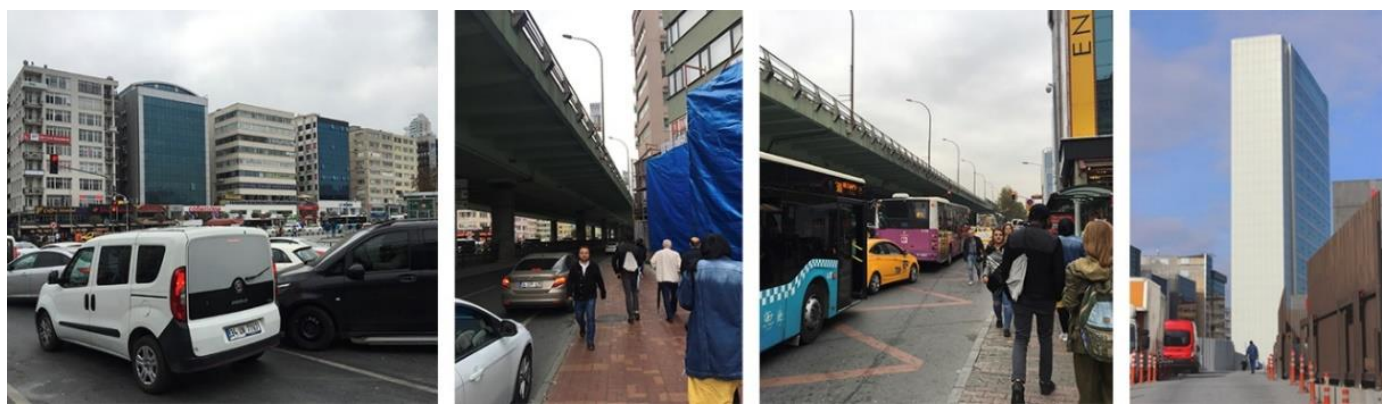

Page | 112

Figure 3 Problems related with pedestrian accessibility in Mecidiyeköy (Photograph credits: personal archive of Feride Gül Keleş, 2019 and Url-5).

Another problematic situation regarding Mecidiyeköy's transfer station identity is the absence of any space to let people who are passing by to meet. There is no well-designed square, public space for people to socialize and enjoy, or there are no sitting or interaction areas. The closest definable place to the square is the place on top of the transitions and roads (Figure 4). These are obstacles for the district to realize its potential as an urban threshold for the citizens.
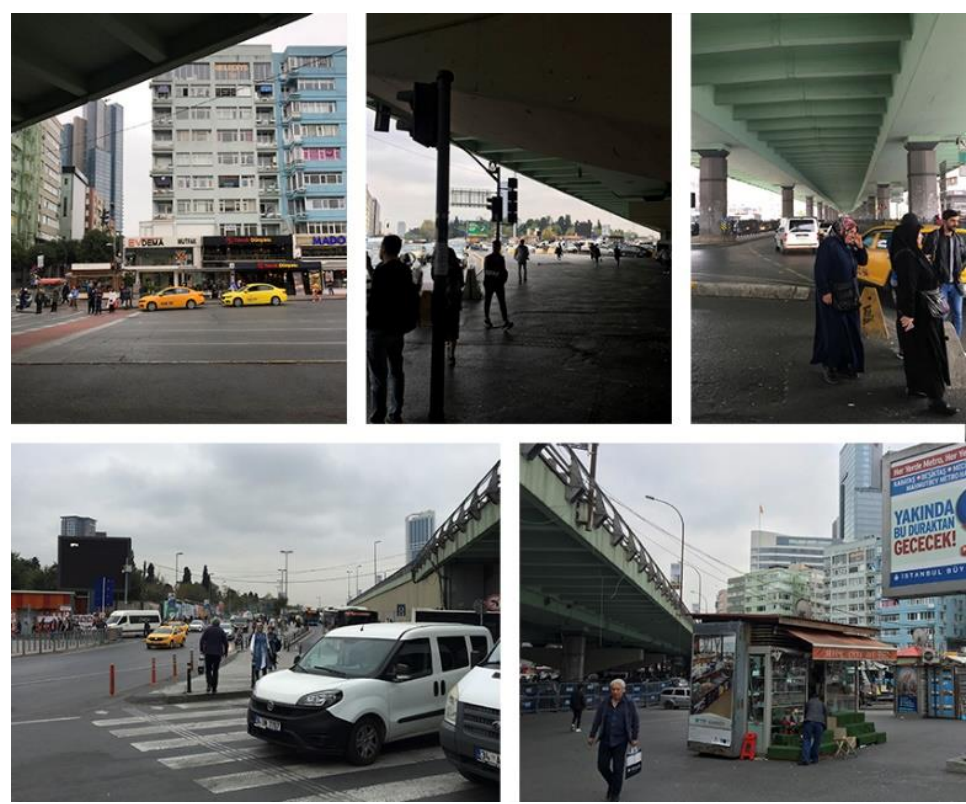

Figure 4 The lack of public spaces in Mecidiyeköy (Photograph credits: personal archive of Feride Gül Keleş, 2019).

Even though there are some open public spaces inside the Torun Center, analyses of this study revealed that those spaces do not act as public spaces for all people; instead, they are mostly open spaces used by those who work there or visit for a short time while passing (Figure 5).
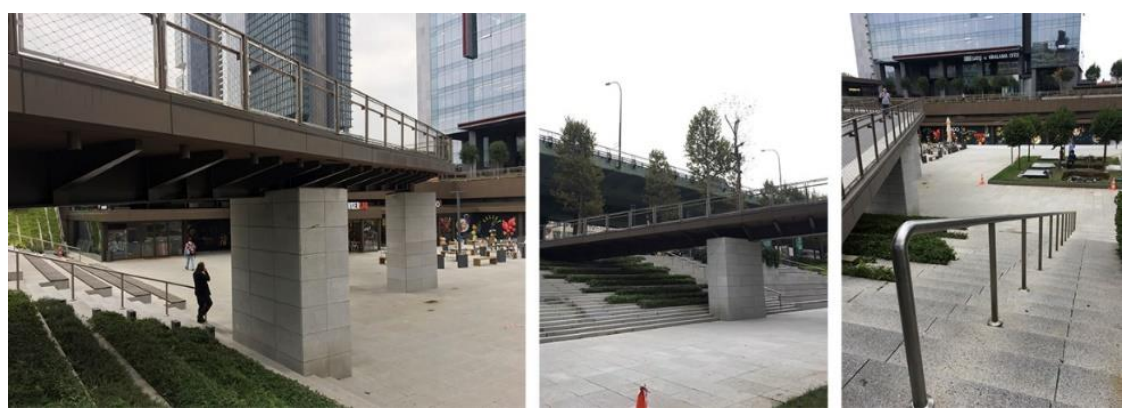

Figure 5 Open spaces of Torun Center (Photograph credits: personal archive of Feride Gül Keleş, 2019). 
Thus, it can be argued that Mecidiyeköy mainly acts as a transition point from one place of Istanbul to another, where the users would not tend to spend a long time as part of their daily practices. In a nutshell, being an easily accessible region with multiple transportation opportunities is not enough for Mecidiyeköy to use its potential as an urban threshold. It should also solve the problems in pedestrian accessibility and provide spaces that would increase the possibilities for people of different socio-economic and age groups to meet and interact with each other.

\subsection{The Identity of Place}

One of the essential elements characterizing Mecidiyeköy's urban space identity is its "hybrid" structure: this is a hybridity that exists both in functional and architectural terms. In the historical process, besides being a residential settlement, Mecidiyeköy has also hosted industrial structures, and today it has an apparent claim of being a center of service, trade, and finance. There are many restaurants, cafes, business centers and the departments of international financial companies in the region.

In the 1950s, changes in the economy and politics based on liberal economic policies in Turkey have paved the way for rural-to-urban migration, and the process of rapid urbanization resulted in an increasing need for housing. In response, the construction of apartment buildings increased, and new formations such as housing cooperatives emerged in addition to individual constructions. Accordingly, Mecidiyeköy, which was surrounded by mulberry gardens until the 1950s, has been opened to housing, and residential settlements have emerged in the 1960s (Anonim, 1994). Today, besides the housing estates consisting of low-rise apartment blocks, Mecidiyeköy also includes some examples of the twentieth century modern Turkish architecture, such as Şişli Hukukçular Sitesi designed by Haluk Baysal \& Melih Birsel for the lawyers' cooperative (Keskinbaş \& Albayrak, 2003). In addition to the increasing numbers of cooperatives and singular housing structures, along the Büyükdere Avenue line, the region started to be characterized by offices, banks, and headquarters (Figure 6).
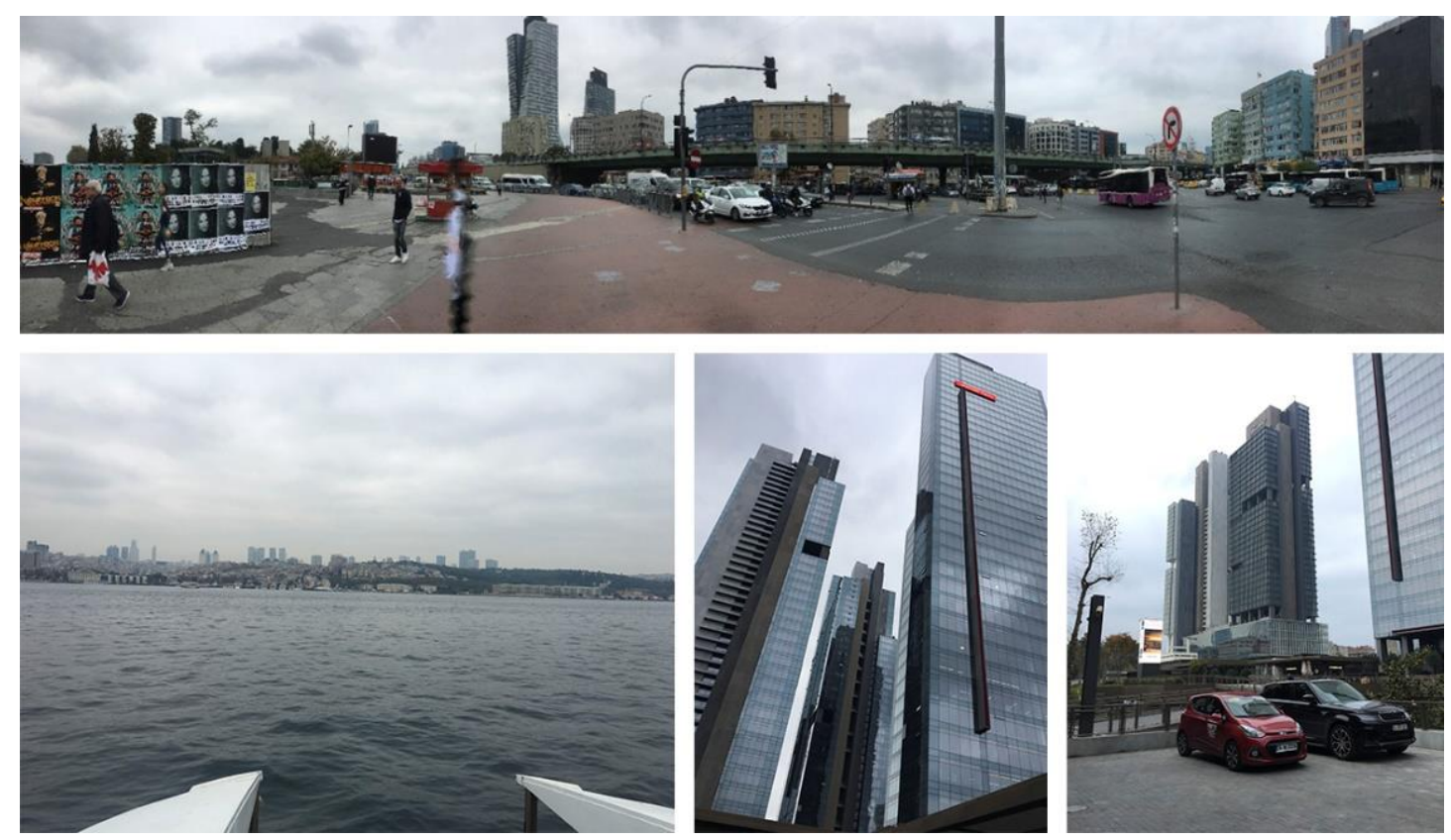

Figure 6 View of Mecidiyeköy from Üsküdar ferry and the financial and trade centers in Mecidiyeköy (Photograph credits: personal archive of Feride Gül Keleş and Uzay Topal, 2019). 
The construction of the Bosphorus Bridge was another breaking point for the history of Mecidiyeköy; the district expanded and transformed into a business center, especially along with the Büyükdere Avenue. Therefore, a functional transformation focusing on trade and traffic has occurred in the district. Since the 1990s, a re-use of residential buildings for commercial purposes has accelerated; such re-use covered the entire building, or only ground floors, for the function of service or trade (Hoseinpournader, 2013). Alongside the penetration of service and trade functions to the residential settlements, multi-story and skyscraper service buildings and commercial centers have started to be built on the Okmeydanı-Çağlayan axis (ex., Trump Towers, Nurol Tower, etc.) and Büyükdere-Beşiktaş axis (ex., Fairmont Quasar Istanbul). Simultaneously, some landmarks that symbolize the historical value of Mecidiyeköy have been transformed into business and trade centers as a representation of the new identity of Mecidiyeköy; to name a few, Mecidiyekoy Liqueur and Cognac Factory and Ali Sami Yen Stadium. Today, the urban character of Mecidiyeköy is shaped through large-scale urban projects defined as "mega projects", which are part of the larger urban policies based on the claim of internationalization of the City of Istanbul.

Fairmont Quasar Istanbul is one of these "mega projects" built in 2018 after demolition of the Mecidiyekoy Liqueur and Cognac Factory in 2012 (Url- 2). Mecidiyekoy Liqueur and Cognac Factory, located in Zincirlikuyu direction of Büyükdere Street and designed by Rob Mallet-Stevens in the 1930s, was a pioneering industrial building in the twentieth century. It was also an essential element of the industrial heritage and urban identity of Mecidiyeköy in the twenty-first century. When the factory was designed, Mecidiyeköy was a non-residential area with its vineyards and gardens, but now it has become an add-on in the project site of a trade and finance complex (Url3). Today, in the earlier factory site, Fairmont Quasar Istanbul is one of the global branches of Fairmont Hotels, and Mecidiyekoy Liqueur and Cognac Factory building is rebuilt and started operating as an art gallery (Figure 7).
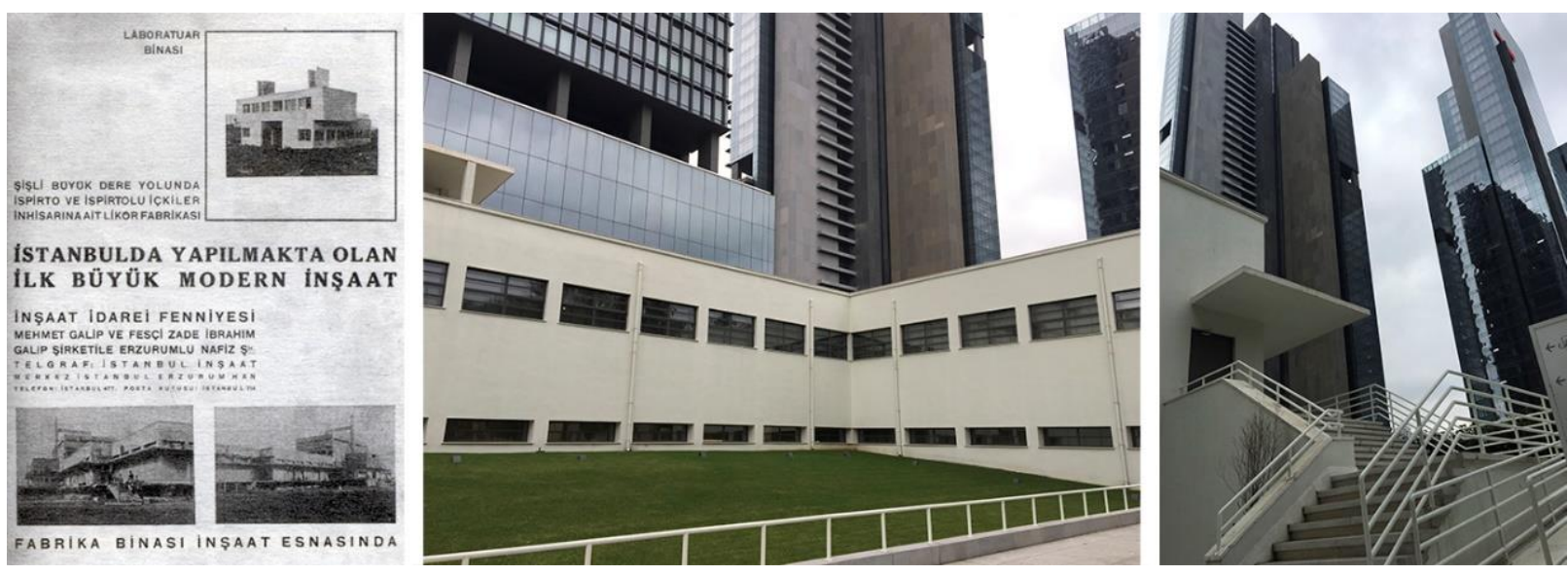

Figure 7 Mecidiyeköy Liqueur and Cognac Factory in 1931 and the rebuilt building as an art gallery in the front with Fairmont Quasar Istanbul (Photograph credits: Url-3 and personal archive of Feride Gül Keleş, 2019).

Another important building that contributed to the urban identity of Mecidiyeköy was Ali Sami Yen Stadium, which was designed by Fazıl Aysu and construction completed in 1964. As part of the construction process of another "mega project" on the site right next to the Mecidiyeköy Liquor and Cognac Factory complex, Ali Sami Yen Stadium was demolished; instead, Torun Center - a residence and office complex- was built, which is designed by Emre Arolat (Url-4). In a nutshell, the demolition of these two landmarks, which have served as important parts of collective urban memory as well as urban identity, is an expression of Mecidiyeköy's emergent identity as a central business center in the European side of Istanbul. 
The residential settlements in Mecidiyeköy are located on the two sides of Ortaklar Street, which cuts Büyükdere Street vertically. Although residential settlements are physically very close to the 'undefined' square of transportation node and the international financial center located parallel to the Istanbul Ring Road and Büyükdere Avenue, they show a great difference in terms of their physical and architectural qualities, as well as their identity. This situation creates a tension between the two. This tension stems from a problematic and artificial coexistence, beyond the separation of public / private spaces. Considering the residential settlements in Mecidiyeköy, it is possible to say that this tension has negative connotations, since there is no space or public space that will strengthen the possibilities of coming together for the residents (Figure 8). The problem also stems from the ignorance of the human scale, which directly shapes the perception of urban space physically. The multi-story residential buildings are surrounded and compressed by commercial and financial structures in the form of skyscrapers (Figure 8).
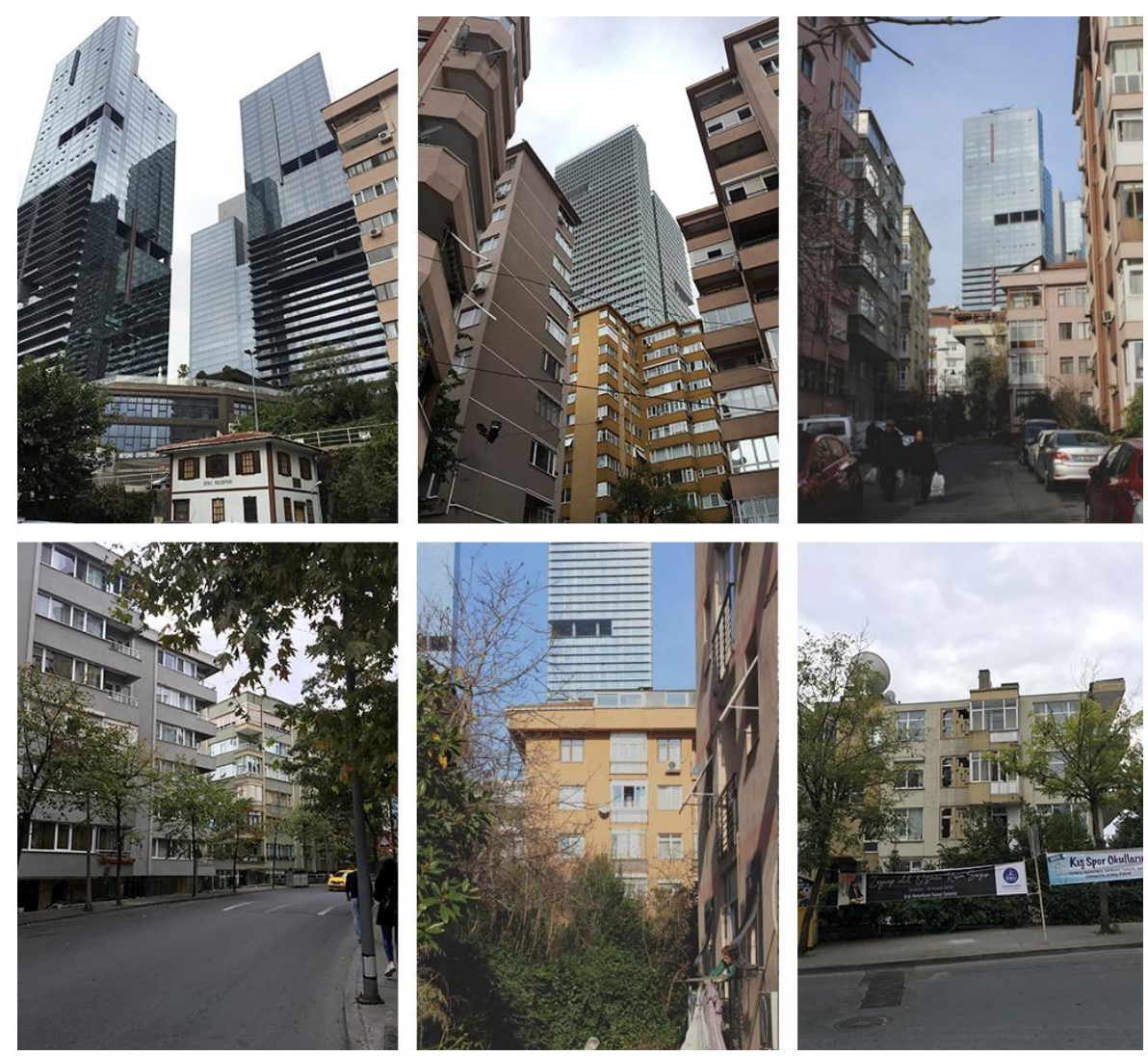

Figure 8 Residential settlements in Mecidiyeköy (Photograph credits: personal archive of Feride Gül Keleş, 2019 and Url$5)$.

\section{Discussion and Conclusion}

Mecidiyeköy's potential status as an "urban threshold" is firstly due to the fact that it constitutes a node of public transportation axes, which plays a vital role for a metropolitan city like Istanbul. While this situation facilitates both vehicular and pedestrian access to the region, the intersection of the transportation axes within the area gives priority to vehicles and does not provide a pedestrian-friendly urban space. The determining role of the transportation network does not allow public spaces to be formed between buildings. Mecidiyeköy's potential status as an urban threshold is secondly due to the hybridity of its functional and architectural elements. Since the mid-twentieth century, the region has been accommodating industrial buildings and housing settlements. From the 1990s to the present, the region has been structured through commercial and financial centers 
that stand out as a reflection of Istanbul's claim for internationalization and taking part in the global economy market.

As a result of the site-analysis, the study revealed that, the interruptions in pedestrian flow, the insufficiency of pedestrian axes, the lack of public space, and the inter-crossing of the highway and metrobus line diminishes the place-making capacity of the square that has a central role in Mecidiyeköy. Moreover, it is revealed that the in-betweenness of residential settlements surrounded by high-rise commercial and financial buildings, not only reduces the quality of urban identity of the area, but also is a barrier against forming an architecturally cohesive urban pattern.

The findings derived from the site analysis revealed that places such as the square in Mecidiyeköy were used only by people as a transition zone due to insufficient urban usage areas. Because of this insufficiency, public spaces started to jump to residential zones. As a result of these leaps, urban flow of daily visitors could not be differentiated from the urban flow that is occurring in the residential zone; this situation negatively affects the formation of the neighborhood identity in the area. Accordingly, the residents have started to adopt a more personal approach, which is completely enclosed and bounded to feel safe. This approach has fueled the marginalization between the public and dwelling areas, or between heterogeneous and homogeneous spaces. Homogeneous spaces can be described as the spaces that refer to the boundaries between urban and rural, public and private, and nature and architecture within the massive impact of globalization (Önder, 2015). The processes shaped by power and consumption relations form continuous, homogenous urban spaces in which urban experience acting within a routine lack of 'event,' and in which urban dwellers are encouraged to be consumers. It can be argued that Mecidiyeköy has become a region where individuals act more as consumers, and less are encountered with the heterogeneous and instantaneous experiences in the society.

Mecidiyeköy acts a region characterized by the encounter, tension and conflict of diverse urban actors. On the 'horizontal' level, an urban section with spatial continuity cannot be formed; instead, one can speak of a dominant 'vertical' urban section that consists of layers of spaces that are physically, experientially, socio-economically and culturally disconnected from each other. It turns into a region where the spatial and public identities become unqualified.

The concept of "threshold" discussed by Stavrides $(2010 ; 2015)$ offered a fertile theoretical ground for the present study to evaluate the potentials and constraints of Mecidiyeköy. This concept, implying contact/separation, continuity/interruption simultaneously, has both social and spatial implications for urban spaces. With reference to Stavrides (2010), Çalışkan, Ribeiro and Tümtürk (2020, p. 35) argue that, the thresholds as hybrid areas where people from different parts of the city will encounter, can become a space for negotiation where the parties become aware of each other. In other words, threshold spaces can act as urban spaces in which the tension between differences is broken and mutual interaction is experienced through dialogue (Şevik \& Çalışkan, 2018). Şevik and Çalışkan (2018) argue that urban thresholds are being formed and realized through pedestrian movement, are accessible, and thus enable integration between different areas and they offer ground for different experiences of urban practices and usages.

Although pedestrian movement is an important element in Mecidiyeköy, the narrowness of the sidewalks suitable for pedestrian flow and the continuous interruption of the pedestrian axis by vehicular network constitute an obstacle to the formation of a fluid threshold experience, both in spatial and experiential terms. Its status as a 'node' of public transportation networks such as buses, minibuses and metrobuses increases the accessibility of Mecidiyeköy; this situation makes it easily accessible from many different parts of the City. However, although it is accessible in terms of vehicular transportation, it is very difficult for the pedestrians to access Mecidiyeköy even from 
areas close to the area such as Beşiktaş and Zincirlikuyu. It is hard to say that the region is pedestrian friendly; therefore, an integration of urban spaces in terms of pedestrian use can hardly be achieved.

While the main factors determining the citizens' spatial experiences in Mecidiyeköy are derived from the functions of trade, service and finance, this situation diminishes the urban experience of users into meeting these needs or just passing through and going to another part of the City. In other words, in terms of the 'affordance' of different urban practices and experience, the notion of 'temporality' characterizes the urban experience of Mecidiyeköy. Instead of being an appealing urban space for social gatherings or cultural public events that would support the formation of social cohesion, Mecidiyeköy turns into a region where spatial experience for most of the users is based on a motivation to leave the area after fulfilling a certain function in a short time.

In the view of Şevik and Çalışkan (2018, pp. 74-76), urban thresholds also act as "third-places", as they are inclusive and support equality of people, encourages dialogue between people and thus, offers a spatial experience in which people feel comfortable and relaxed. The "third space" concept is adopted from the view of space as social production that was firstly introduced by Henri Lefebvre and has been extended by Edward Soja especially in the social production of space. Soja introduced the "third space" concept that approaches spatiality through the investigation of three types of space: the first space (perceived space), the second space (conceived space), and the third space (lived space) (Soja,1996; Li \& Zhou, 2018). The relationship between these three types of spaces is transformed into place meaning. The meaning is studied through the quality of spaces, people's activities, particular histories, and people's perceptions of their environment. The people living in Mecidiyeköy, the people who come to work in Mecidiyeköy and the people who come to perform their daily activities in Mecidiyeköy create a great variation in terms of urban identity. The lack of public spaces that would support communication and interaction between these different groups makes it difficult to reproduce the space through experience, which would result in the formation of "third space." The absence of urban voids that would allow for coincidental encounters, bring citizens together and trigger new communication possibilities, further exacerbates this challenge.

This article revealed that socio-cultural sustainability, as a conceptual framework and urban approach, can provide a fertile ground for future urban scenarios that would be developed for Mecidiyeköy. If approached from the socio-cultural sustainability perspective, it can be ensured that this region has constraints and potentials in terms of accommodating spatial and human diversity and triggering the interaction between them; yet this region can also act as an "urban threshold." Reconsidering urban planning and architectural process through the perspective of socio-cultural sustainability is essential and inevitable not only for Mecidiyeköy, but also for the whole city of Istanbul, in order to give room for the possibilities of encounters between individuals from different socio-economic or socio-cultural groups of the society. In conclusion, socio-cultural sustainability provides opportunities for policy-makers, urban planners, architects and researchers in all these fields to investigate and envisage new strategies for enhancing not only the physical quality of urban spaces, but also the quality of life of the urban residents.

\section{Further Note:}

This article is based on the research conducted within the ARCH 502-Project Course in the 20192020 Fall Semester in Özyeğin University Faculty of Architecture and Design, MSc in Architecture Program. 


\section{References}

Anonim. (1994). Mecidiyeköy. In Dünden Bugüne Istanbul Ansiklopedisi (Vol. 5, pp. 317-318). Istanbul, Turkey: Kültür Bakanlığı Tarih Vakfı.

Artuç, D. (2016). Kentsel dönüşümün sosyal ve mekânsal etkileri: Fikirtepe dönüşüm alanı [Master's thesis, Maltepe University]. Istanbul, Turkey.

Colantonio, A., \& Dixon, T. (2011). Urban regeneration \& social sustainability: best practice from European cities. Wiley-Blackwell.

Çalışkan, O., Ribeiro, D. C., \& Tümtürk, O. (2020). Designing the heterotopia: from social ideology to spatial morphology. Urban Design International, 25(1), 30-52.

Dempsey, N., Bramley, G., Power, S., \& Brown, C. (2011). The social dimension of sustainable development: Defining urban social sustainability. Sustainable development, 19(5), 289-300.

Dişli, E. Y. (2006). Toplu taşıma sistemleri entegrasyonu ve Şişli Mecidiyeköy uygulaması [Master's thesis, Istanbul Technical University]. Istanbul, Turkey.

Dixon, T. (2011). Putting the s word back into sustainability: can we be more social? The Berkeley Group, Oxford Brookes University.

Gür, A. (2019). Integration of public transport services: the case of Istanbul [Master's thesis, Middle East Technical University]. Ankara, Turkey.

Hediger, W. (2000). Sustainable development and social welfare. Ecological economics, 32(3), 481-492.

Hertzberger, H. (1991). Lessons for students in architecture. 010 Publishers.

Hoseinpournader, S. (2013). Mecidiyeköy-Zincirlikuyu aksında turizm, hizmet, ticaret ve konut alanlarının tarihsel gelişim sürecinin irdelenmesi [Master's thesis, Yıldız Technical University]. Istanbul, Turkey.

Istanbul Metropolitan Municipality (IMM), Metro Istanbul. Retrieved April 4, 2021 from https://www.metro.Istanbul/haber/detay/m7-hatti-gunluk-100-bin-yolcuya-ulasti

Karaman, O. (2008). Urban pulse-(RE)Making space for globalization in Istanbul. Urban Geography, 29(6), 518-525.

Karuppannan, S., \& Sivam, A. (2011). Social sustainability and neighbourhood design: an investigation of residents' satisfaction in Delhi. Local Environment, 16(9), 849-870.

Kesikbaş, N., \& Albayrak, F. (2003). Melih Birsel'le söyleşi. Yapı, 256, 45-48.

Keyder, Ç. (2000). Istanbul: küresel ile yerel arasında. Metis Yayınları.

Lefebvre, H. (1992). The production of space. Wiley-Blackwell.

Li, X., \& Zhou, S. (2018). The trialectics of spatiality: the labeling of a historical area in Beijing. Sustainability, 10(5), 1542.

Mitlin, D., \& Satterthwaite, D. (1996). Sustainable development and cities. In C. Pugh (Ed.), Sustainability the Environment and Urbanization (pp. 23-62). Earthscan Publications.

Mutman, D., \& Yorgancıoğlu, D. (In press). Re-reading the tools and actors: commodification of urban space and promoting the image of 'new' Istanbul [Special issue: Turkey, Urbanism and the New Habitat, Oktay (Ed.)]. Ekistics and the New Habitat, 80(1).

Oktay, D. (2014). Kent, sürdürülebilirlik ve yaşam kalitesi Eskişehir Kent Sempozyumu, Eskişehir, Turkey.

Önder, D. (2015). Kent deneyiminde özgürleşme aralıkları olarak heterojen mekân [Master's thesis, Istanbul Technical University]. Istanbul, Turkey.

Ozus, E., Turk, S. S., \& Dokmeci, V. (2011). Urban restructuring of Istanbul. European Planning Studies, 19(2), 331-356.

Sachs, I. (1999). Social sustainability and whole development: exploring the dimensions of sustainable development. In T. Jahn \& E. Becker (Eds.), Sustainability and the social sciences: a cross-disciplinary approach to integrating environmental considerations into theoretical reorientation (pp. 25-36). Zed Books.

Soja, E. W. (1996). Thirdspace: journeys to Los Angeles and other real-and-imagined places. Wiley-Blackwell.

Stavrides, S. (2010). Towards the city of thresholds. Professionaldreamers.

Stavrides, S. (2015). Common space as threshold space: Urban commoning in struggles to re-appropriate public space. Footprint, 16, 9-19.

Şevik, E. (2018). Territoriality of heterotopia: threshold as a condition of heterotopian space in the case of Emek district, Bursa [Master's thesis, Middle East Technical University]. Ankara, Turkey.

Şevik, E., \& Çalışkan, O. (2018). Heterotopyanın alansalığı: heterotopolojinin temel mekânsal koşulu olarak kentsel eşikler II. Kentsel Morfoloji Sempozyumu, Istanbul, Turkey.

Tekeli, ì. (2013). Istanbul'un planlanmasının ve gelișmesinin öyküsü. Tarih Vakfı Yurt Yayınları.

Teyssot, G. (2008). Mapping the threshold: "a theory of design and interface". AA Files, 57, 3-12. 
The World Commission on Environment and Development (1987). Our common future. Oxford University Press.

Woodcraft, S. (2012). Social sustainability and new communities: moving from concept to practice in the UK. Procedia-Social and Behavioral Sciences, 68, 29-42.

Url 1 Yıldızgördü, O. (2019). Analysis of Mecidiyeköy and Üsküdar in the context of socio-cultural sustainability. Retrieved March 5, 2021 from https://youtu.be/WKzSpz2_Zok

Page| $119 \quad$ Url 2 Istanbul, M. Quasar Istanbul (Tekel Likör ve Kanyak Fabrikası). Retrieved March 5, 2021 from http://megaprojelerlstanbul.com/\#quasar-Istanbul-mecidiyekoy-likor-fabrikasi

Url 3 Civelekoğlu, L. Likör uğruna Istanbul'a kadar gelen bir "Parisien": Mimar Rob Mallet-Stevens. Retrieved February 26, 2021 from http://Icivelekoglu.blogspot.com/2013/11/likor-ugruna-Istanbula-kadar-gelenbir.html

Url 4 Istanbul, M. Torun Center (Ali Sami Yen Stadı). Retrieved March 5, 2021 from http://megaprojelerlstanbul.com/\#torun-center-ali-sami-yen-stadi

Url 5 Rodoplu, B. G. (2019). As they tower over you. https://issuu.com/gunrodoplu/docs/fad413final_g_nrodoplu

Keleş, F. G. (2019). In. Personal archive.

Rodoplu, B. G. (2019). In. Personal archive.

Topal, U. (2019). In. Personal archive.

Yıldızgördü, O. (2019). In. Personal archive.

\section{Resume}

Olcay Yıldızgördü graduated from Özyeğin University as an architect in 2019, and she received an acceptance from Architecture M.Sc. in the same year. She is still on her master studies in Architecture at Özyeğin University. Her research interests include culture and space studies, housing design and research, globalization and its effects on new housing trends, and Turkey's modern architectural history.

Derya Yorgancıoğlu received her B.Arch (2000) degree from Yıldız Technical University Department of Architecture (2000), and M.Arch (2004) and Ph.D. (2010) degrees in Architecture from the Middle East Technical University Department of Architecture. She worked as Assistant Professor at the Department of Architecture at Istanbul Kemerburgaz University (2011-2017). Currently she is working at Özyeğin University Department of Architecture. She conducted short term research studies at Queen's University of Belfast, Center for Educational Development (CED) in 2017 and at Indiana University, Bloomington, Center for Innovative Teaching and Learning in 2018 as a short-term visiting researcher. Her research project was granted by the Scientific and Technological Research Council of Turkey (TUBITAK) [grant number 215K234]. Her research interests cover the fields of theory and research in architecture, architectural design, architectural education, learning space design, scholarship of teaching and learning in higher education. 